㘥

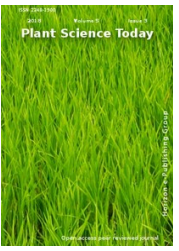

OPEN ACCESS

\title{
CORRECTION
}

\section{Correction to: Bryophyte diversity of Thamarassery pass (Wayanad pass) in the Western Ghats of Kerala}

\author{
Mithun Venugopal, Manju $\mathrm{C} \mathrm{N}^{*}$ \\ Department of Botany, The Zamorin's Guruvayurappan College, Kozhikode, Kerala, India (affiliated to the University of Calicut)
}

\section{Article history}

Correction request: 10 July 2018

Published: 26 July 2018

\section{Publisher}

Horizon e-Publishing Group

\section{*Correspondence}

Manju C. N.

\manjucali@gmail.com

\section{Citation}

Venugopal M, Manju C N. Correction to: Bryophyte diversity of Thamarassery pass (Wayanad pass) in the Western Ghats of Kerala. Plant Science Today 2018;5(3):127. https://dx.doi.org/10.14719/pst.2018.5.3.410

Copyright: (c) Venugopal and Manju (2018). This is an open-access article distributed under the terms of the Creative Commons Attribution License, which permits unrestricted use, distribution, and reproduction in any medium, provided the original author and source are credited (https://creativecommons.org/licenses/by/4.0/).
Correction to: Plant Science Today 4(1): 41-48.

http://dx.doi.org/10.14719/pst.2017.4.1.273

The original version of this article unfortunately contained a mistake. The funding source was wrongly cited in the original version of the article under Acknowledgements section, the authors have now provided correct information. The authors apologize to the readers of Plant Science Today for the inconveniences caused by this oversight.
The corrected funding information is provided under the Acknowledgements as given below:

\section{Acknowledgements}

The authors are thankful to the authorities of Vallkkattu Kavu for giving permission to collect specimens from the area and the support during the visit. The authors are thankful to the Kerala State Council for Science Technology \& Environment (KSCSTE) for financial assistance as student project. We also acknowledge the support provided by the authorities of the Zamorin's Guruvayurapan College, Kozhikode. 